\title{
Register Theory in Functional Linguistics and its Implication in Language Teaching
}

\author{
Zhang Ling \\ School of Foreign Languages and Cultures, Beijing Wuzi University, Beijing, 101149, China \\ irene_zhangling@hotmail.com
}

\begin{abstract}
In China, the students learning English usually put great emphasis on its accuracy rather than on appropriateness. This paper is attempt to show how conceptions of register can begin to be applied in language teaching. The results show that linguistic knowledge of register can not only benefit English teachers but also learners a lot in their English teaching or learning.

Index Terms - register, functional linguistics, language learning.
\end{abstract}

\section{An overview of systemic functional linguistics}

Systemic functional linguistics (SFL) is primarily a linguistic theory. It is one variety of functional linguistics, its distinctive feature is to explain "the internal organization of language in terms of the functions that it has evolved to serve" (Halliday, 1994, p.1).

The concept of function is fundamental in Halliday's systemic-functional grammar theory. Halliday views language development in children "as the mastery of linguistic functions" and learning language, according to him, is "learning how to learn". As the child grows, his language also changes in terms of function. The adult's language becomes much more complex and it has to serve many more functions. However, the original functional range of the child's language is gradually reduced to a set of highly coded and abstract functions in a systematic and finite form, which are called "meta-functions". Language now provides the mechanisms for different functions to be combined in one utterance in the way the adult desires. Halliday recognizes three meta-functions: "ideational, interpersonal, and textual functions" as follows (1978, p.19).

The ideational function "serves for the expression of content": that is, of the speaker's experience of the real world, including the inner world of his own consciousness."

(Halliday, 1970, p.143). The ideational function represents the speaker's meaning potential as an observer. This is the function through which the speaker encodes his own individual experience as a member of the culture. It expresses the phenomena of the environment the things-creatures, objects, actions, events, qualities, state; and relations of the world and of our own consciousness, including the phenomena of language itself and also the "metaphenomena," the things that are already encoded as facts or reports. All these are part of the ideational meaning of language. The ideational function is divided into the experiential function and the logical function. The former consists of processes, participants in those processes, circumstances, and the like; while the latter consists of such relations as coordination, subordination, conjunction, etc.
The interpersonal function "serves to establish and maintain social relations: which include the communication roles questioner or respondent, which we take on by asking or answering a question; and also for getting things done, by means of the interaction between one person and another" (Halliday, 1970, p.143). The interpersonal function represents the speaker's events, expressing his attitudes, evaluations, judgments, expectations and demands. It also includes the speaker's comments on the probabilities, necessity, and the like.

The textual function represents the speaker's textforming potential. "It provides for making links with itself and with features of the situation in which it is used. It enables the speaker or writer to construct text, or connected passages of discourse that is situationally relevant" ( Halliday, 1970, p.143).

Therefore, "unlike other linguistic theories, in systematic functional linguistics, the social and cultural role of language is a central concern" (Coffin, 2001, p.94). It means that the central concern of systemic functional linguistics is how language is structured to achieve sociocultural meanings and how people use language with each other to accomplish everyday social life. So it is clear that one of the most important features of SFL is that the theory is designed to explain the interrelationships between culture, society and language use. So the concepts of "context of culture", "context of situation" and "register" are used in systemics to explain this relationship (Coffin, 2001, P. 95). Thus, they will be discussed in following parts.

\section{Register}

\section{A. Historical reviews on register}

Within the various European traditions, the most influential body of work on register stems from what we might refer to as "British contextualism" (Eggins, S \& Martin, J.R. , 1997, p.237). The study on context has been going on for a long time. Two important early studies focusing on situated language are Malinowski's discussion of the "context of situation" and Firth's elaboration of that concept (Biber, 1995). In Eggins' (2004, p.88-89) description, Malinowsk originally suggested the basic concept of context of situation. He views language as function in context. According to him, language is a model of action, rather as a counterpart of thought. The meaning of an utterance does not come from the ideas of the words comprising it but from its relation to the situational context in which the utterance occurs. In observing 
the fishing and agricultural practices of the native inhabitants of the island, he realized that in order to understand what was going, it was not enough to understand and write down the meaning of their words. One has to understand why they said what they said and how they said it to whom in specific "context of situation". In addition, one has to link their words, beliefs, and mind-sets to a larger "context of culture", such as tribal economics, social organization, kinship patterns, seasonal rhythms, concepts of time and space.

Malinowski's notion was further developed and made explicit by Firth, who maintained that the context of situation was not to be interpreted in concrete terms as a sort of audiovisual record of the surrounding "props" but was, rather, an abstract representation of the environment in terms of certain general categories having relevance to the text (1957, p.182).

\section{B. Halliday's register theory}

Halliday took a functional approach to view language as an instrument of social interaction. For Halliday, "the contexts in which meanings are exchanged are not devoid of social value; a context of speech is itself a semiotic construct, having a form (deriving from the culture), that enables the participants to predict features of the prevailing register-and hence to understand one another as they go along" (1978, p.2). And "context plays a part in determining what we say; and what we say plays a part in determining the context. As we learn how to mean, we learn to predict each from the other"(Halliday, 1978, p.3). In this sense, context acts as an interface between the levels of culture (situation) and form (grammar, lexis) and is concerned with relationships between all these levels and the situation.

In the process of investigating the interaction of language and the social system, Halliday defined register as "variation according to use" (Halliday \& Hasan, 1985, p.89). It is a language variety that is associated with the different use in different situations. He is interested in discovering how it is possible for native speakers, drawing upon their knowledge of register, to predict a lot about the language that will occur in a given situation, or a social context of use. These predications through register are determined by three categories of features of the situation: what is going on, who is taking part, and what part language is playing, that is, whether it is spoken or written or in the form of a monologue, dialogue, letter, or newspaper report. Halliday presents the semiotic structure of a situation under three headings, namely, field, mode and tenor, which form the integrated system of "register" (1994, p.26). Thus in the following section I will give a general description of register theory of the systemic-functional linguistics.

\section{Concept of register}

In systemic-functional linguistics, register theory indicated the relationship between context and language from a socio-semiotic perspective. A text is produced in a specific context of situation. Halliday regards "context of situation as the contextual variables of Field , Tenor and Mode"(1985, p.12).
Field refers to what is going on, where what is going on is interpreted institutionally in terms of some culturally recognized activity (what people are doing with their lives, as it were). When people ask you what you do when first getting to know you, you tend to answer in terms of field (Martin, 2001, p.152). Examples of fields are activities such as tennis, opera, cooking, farming, politics, education and so on. Eggnis defines "field of discourse as what the language is being used to talk about" (2004. p.90). This variable included not only the specific topic of discourse, but also the degree of technicality or specialty on the one hand or everyday quality on the other. In other word, what we are writing or talking about will determine whether the field of discourse is technical or non-technical. If we are talking about politics in newspapers, writing a term paper, giving a mathematic lecture, etc, the technical registers will be needed and consequently the formal style of language is found. But when we are casually chatting with friends about weather, play, sports, games, non-technical registers are established and informal styles will be demonstrated.

Tenor refers to "the way you related to other people when doing what you do. One aspect of this is status" (Martin, 2001, p.153). Gerot and Wignell claim that the tenor refers to "the social relationships between those taking part in terms of status or power, affect and contact" (1994, p.11). In other words, it implies that people are more likely to choose the appropriate language forms unconsciously according to their status in relation to one another. For example, with close friends or colleagues we are informal but not to the same degree. When we are talking to someone in a high position over us, our language will become more formal. We can imagine that when the conversation happened between teachers and students or bosses and employees, the former would be likely to dominate the latter in conversation because their different status or power.

For example, when asking the other ones to keep silence, we may express it in following ways:

1) Your silence is required.

2) Quiet, please.

3) Would you be so good?

4) Do shut up.

5) Put a sock in it.

6) Drop dead!

From these sentences we may consider, the speaker's tone varies from very polite to impatient and even quite angry. The levels of formality of these sentences also vary from the highest to the lowest.

Mode refers to "the channel you select to communicate" (Martin, 2001, p.153). That means the choice you most commonly presented is between speech and writing. Gerot and Wignell argue that it includes three points: how language is being used? Is the channel of communication spoken or written? And is language being used as a mode of action or reflection (1994, P.11)? For example, a student who wants to ask for a leave had to select a channel to communicate with his or her teacher. The student can chose face-to face or via telephone, even e-mail to achieve his or her purpose. 
Generally, choice of channel may sometimes depend on the previous choice of role--- tenor, but this is not necessarily the case. For most of us, the channel of speaking and listening is used much more than reading and writing. Painter concludes that "tenor is concerned with the social distance between interactants, whereas mode considers the effect of physical distance" (2001, p.175)

\section{Register analysis in text}

The SFL approach to register believes that language is shaped and organized to form different types of texts depending on a speaker or writer's social purpose. And teachers can apply SFL to both written and spoken English. Thus, as a teacher, the first thing in the instruction is to illustrate the features of register: what the text tells about; who is the reader; what's the purpose; in what attitude and what way to organize the article; etc. In other words, in text analysis, register analysis plays a key role. And we may take the following text for example.

\section{Text}

And if it were willing to pay, long prison sentences may not be effective in reducing crime. In 1981, 124, 000 convicts were released from prison. If we had kept them in jail for an additional year, how many crimes would have been prevented? While it is not possible to know the true amount of crime committed by people released from prison in any given year, we do know the extent to which those under parole are jailed against for major crime convictions. This number is a surprisingly low 6 percent (after three years it rises to only 11 percent). Even if released prisoners commit an average of two crimes each, this would amount to only 15, 000 crimes prevented: a drop in the bucket when measured against the 41 million crimes committed each year.

More time spent in prison is also more expensive. The best estimates are that it costs an average of $\$ 13,000$ to keep a person in prison for one year. If we had a place to keep the 124.000 released prisoners, it would have cost us $\$ 1.6$ billion to prevent 15, 000 crimes. This works out to more than $\$ 100$, 000 per crime prevented. But there is more. With the average cost of prison construction running around \$50, 000 per bed, it would cost more than $\$ 6$ billion to build the necessary cells. The first-year operating cost would be \$150, 000 per crime prevented, worth it if the victim were you or me, but much too expensive to be feasible as a national policy. (Moran, 2002, p.57-58)

The text first appeared in Newsweek on May 7, 1984. Obviously, news is a major register of language. "Understanding how it works is important to understanding the functioning of language society"(Bell, 1991, p.12). And the fundamental purpose of register analysis is to find out what situational factors determine what linguistic features.

Journalist English, as a familiar variety in modern English, is used widely in newspapers, periodicals, broadcasting and television and so on. According to the theory of register, it can be divided into three types: in terms of field, journalistic English cover everything ranging from politics to economy, society, science, crime and so on; in terms of tenor, "it intends to provide the latest information in news reporting, editorial, features, comments, letters to editor, classified advertisements, reviews, book reviews, weather reports and fashion columns" (Bhatia 1993.p.157). In terms of mode, it may be either printed on paper, or broadcast on radio or television.

According to the theory of Halliday: we define the business news report in this way:

Field: "field is the social activity in which the text is produced, the subject being its special manifestation" (Halliday, 1994, p.10). In this news reporting, it provided us with the latest news about crime in USA. It provides straightforward information rather than instruction or persuasive message on crime prevention. This concept also decided the vocabulary features. For example, the use of numbers is frequent in the news. Tuchman regards "number is the most verifiable, quantifiable, and undeniable of fact'(Tuehnlna , 1978, p.34). In this text, the writer routinely uses numbers to make news stories convincing and reliable. Typical news numbers include dates, dollars, percentage and length of time.

Tenor: in this text, tenor refers reader, indirect interaction between a news writer and a wide public. The role relationship is between the participants in the activity. One characteristics of this text is to guide the readers to predict the further development of the crime event. As a result, the forward-looking statements always appear in the text. As a sub-genre of news, the reporter seldom used modal expression to state a fact and the density of modality is sparse.

Mode: in this text, the crime news reporting limited to the written texts, where face-to-face interaction is impossible. The final purpose of news reporting is to inform or report. And the focus in the text is the crime event. As we know, there is an absence of addressee in the direct communication process. Thus, the reporter cannot receive the reactions of readers in the process of communication. Therefore, the marked themes used in the texts can be regarded as the realization of the writer's careful planning of the development of the text. Examples from above text are:

1) And if it were willing to pay, long prison sentences may not be effective in reducing crime.

2) More time spent in prison is also more expensive.

\section{The application of register theory to English teaching}

\section{A. The prediction of meaning and situation by register in language learning}

We can gather information about the field of activity, the participant role relationships involved, and the part played by language in the process. With the three determinants of register, a prediction can be made during the process of language communication. If the entries under field, tenor, mode are filled out carefully and thoughtfully, it is surprising how many features of the language turn out to be related to the context of situation. This is not to claim that we know what the participants are going to say; it merely shows that we can make sensible and informed guesses about certain aspects of 
what they might say, with a reasonable probability of being right. According to Halliday's point of view, people make prediction in two directions: prediction from context to text and from text to context. When speaking or writing, the participants make prediction from context to text. That is to say, by making inferences of what is going to be said or written in certain context of situation, participants predict which grammatical items and vocabulary are selected in communication. For example, we can predict what a doctor and a patient are talking about in the hospital; what they are talking about probably concerns the patient in consulting about his state of an illness; the vocabulary selected is probably related to health, illness, pains, hurt, etc; the textual structure is dialogue.

Contrasting with this, the process of prediction from text to context is from the lexico-grammatical level through the semantic level to the context of situation, when in listening and reading. For example, hearing "Ladies and gentlemen, welcome to my research report." we may predict that someone is delivering a speech. When hearing "Long long ago...", we predict that someone is telling story. We are always listening and reading with expectations, and the notion of register is really a theory about these expectations, providing a way of making them explicit. That we can predict from context to text and from text to context is just how the register works.

\section{$B$. The mirror of culture by register in language learning}

As we all know that, culture plays an important role in communication. Whenever human beings communicate with each other, culture is involved, acted out, transmitted and preserved through communication. The use of language is greatly influenced by culture, which is the total cultural background shared by one community. Because the social and cultural backgrounds between English and Chinese are greatly different, the registers of these two languages, of course, are different. As for English, if we survey it in the aspect of syntax, there exist obvious differences between special language and common language. And the differences between varieties are also very apparent. Compared with English, Chinese does not have such obvious differences between special language and common language. For example, we can divide English into legal English, business English, scientific and technical English etc, whereas in Chinese, it seems that we do not clarify legal Chinese, business Chinese, scientific and technical Chinese. So when we communicate with the foreigners it is necessary for us to understand the differences between these two languages, especially registers and levels of formality. We have known that register is a set of meanings that is appropriate to a particular function of language, together with the words and structures, which express these meanings. The social environment, as well as social structures, can be reflected in a language and can often have an effect on registers of that language. Sometimes communication can be made extremely difficult because of cultural diversity in perceiving the same thing.

For example, when two Chinese happen to sit next to each other in a train to Beijing, a conversation goes on like this:

\author{
"Where will you get off?" \\ "Beijing!" \\ "What do you go to Beijing for?" \\ "I study at Peking University." \\ "Oh! Great! But you look very young. How old are you?" \\ "I am twenty-seven years old. How about you?" \\ "I am forty-three years old."
}

Suppose the meeting happens between a Chinese and an Englishman, the conversation cannot go on because so many private things are involved, which westerners try to avoid. Therefore, awareness of cultural diversity can make great difference in the process of communication. Everyone knows that English and Chinese are completely different languages: the former is alphabetic; the latter is ideographic. The two languages originated from two completely different cultures. There are many differences in every aspect. Consequently, a Chinese person has many difficulties in learning English. From the perspective of English teacher, we should pay attention to this point in English classroom.

\section{Conclusion}

In this paper, I have attempted to show how conceptions of register can begin to be applied in language teaching. In China, the students learning English usually put great emphasis on its accuracy rather than on appropriateness. The result is that even if they have been perfect in vocabulary and grammar, they cannot recognize and use different speech registers in communication, nor can they communicate appropriately and effectively in a foreign language. Real mastery of a language consists not only in the ability to construct grammatically correct sentences, but in the ability to choose the proper register according to particular circumstances or contexts. The choice of items from wrong registers prevents communication from going on smoothly. To choose the proper register means firstly to choose the correct vocabulary, the correct style, and then, a further consideration of cultural items involved.

As Chinese English teachers, we must be alert to the ignorance of appropriateness not only in learners' behavior, but also in our own instruction. In English teaching practice, the primary importance should be attached to registers, in the way that teachers should equip themselves with the sense of register in the first place, and then it would be possible for the students to be trained for sensitivity to register variations. When we observe language activities in various contexts, we find differences in the registers selected as appropriate and acceptable to different types of situations.

As a matter of fact, linguistic knowledge of register can not only benefit English teachers but also learners a lot in their English teaching or learning. For teachers, a consciousness of register enables them to identify and focus on whatever aspect of language in use the learner needs most help with. For learners, they may make a systematical progress in language learning by familiarity with the culturally expected schematic structure or by learning an abundant of technical vocabulary for the field, or by adequate experience of the desired tenor or a sophisticated mode. 


\section{References}

[1] Bell, A. (1991). The language of news media. Oxford: Basil Blackwell Ltd.

[2] Bhatia V. (1993). Analyzing Genre. London: Longman. Biber, D. (1995). Dimensions of register variation: a cross-linguistic comparison. London: Cambridge University Press.

[3] Coffin, C. (2001). Theoretical approach to written language - a TESOL perspective. In Burns, A. \& Coffin, C. (Eds.), Analyzing English in a global context. (pp.93-122).London: Routledge.

[4] Eggins, S. (2004). An introduction to systemic functional linguistics (2nd ed.). London: Continuum.

[5] Eggins, S. and Martin, J. R. (1997). Genres and registers of discourse: discourse as structure and process. London: Publications.

[6] Firth, J. R. (1957). Papers in linguistics 1934-1951. London: Oxford University Press.

[7] Gerot, L. \& Wignell, P. (1994). Making sense of functional grammar. Sydney: Antipodean Educational Enterprises.

[8] Halliday, M. A. K. (1970). Language Structure and Language Function. In Lyons, J (Ed), New horizons in linguistics (pp.128-169).

Harmondsworth: Penguin.
[9] Halliday, M. A. K. (1978). Language as social semiotic. London: Arnold.

[10] Halliday, M. A. K. (1994). An introduction to functional grammar (2nd ed.). London: Arnold.

[11] Halliday, M. A. K, \& Hasan, A. S. (1985). Language, context, and text: aspects of language in a social-semiotic perspective. Victoria: Deakin University Press.

[12] Martin, J. R. (2001). Language, register and genre. In Burns, A., \& Coffin, C. (Eds.), Analyzing English in a global context. (pp.149-166). London: Routledge.

[13] Moran, R. (2002). More crime and the rose. In Yang, L. M. (Eds). Contemporary college English.(pp.56-58). Beijing: Foreign Language Teaching and Research Press.

[14] Painter, C. (2001). Understanding genre and register: implications for language teaching. In Burns, A., and Coffin, C. (Eds.), Analyzing English in a global context. (pp.167-180).London: Routledge.

[15] Tuehnlna, G. (1978). Making news: a study in the construction of reality. New York: Free Press. 